\title{
Characterization of a New Potyvirus Naturally Infecting Chickpea
}

Richard C. Larsen, USDA, ARS, Prosser, WA 99350; Walter J. Kaiser, U.S. Peace Corps Volunteer, Sucre, Bolivia; Stephen D. Wyatt and Keri L. Buxton-Druffel, Department of Plant Pathology, Washington State University, Pullman 99164; and Phillip H. Berger, Department of Plant, Soil and Entomological Sciences, University of Idaho, Moscow 83844

\begin{abstract}
Larsen, R. C., Kaiser, W. J., Wyatt, S. D., Buxton-Druffel, K. L., and Berger, P. H. 2003. Characterization of a new potyvirus naturally infecting chickpea. Plant Dis. 87:1366-1371.

During the 1999 to 2001 growing seasons, symptoms consisting of mosaic, stunting, yellowing, wilting, shortening of internodes, and phloem discoloration were observed in chickpea (Cicer arietinum) grown in the Department of Chuquisaca in southern Bolivia. In some fields, approximately $10 \%$ of the plants exhibited viruslike symptoms and suffered greatly reduced seed yields. Lentil (Lens culinaris) was also observed to be infected but not pea (Pisum sativum) or faba bean (Vicia faba) growing in nearby fields. Infected chickpea tissue reacted positively to the potyvirus group-specific monoclonal antibody (MAb), but there was no serological reaction with antisera to the potyviruses Bean yellow mosaic virus, Clover yellow vein virus, Cowpea aphid-borne mosaic virus, Pea seedborne mosaic virus, Bean common mosaic virus, or Bean common mosaic necrosis virus. Western blots of total protein extracts probed with the potyvirus $\mathrm{MAb}$ revealed a single band ca. $32 \mathrm{kDa}$. Comparative sequence analysis of cDNA clones generated from the putative coat protein gene consisted of 282 amino acids ( $31.9 \mathrm{kDa})$ and showed moderate identities of $67,66,63,63$, and $61 \%$ with the coat proteins of potyviruses Pepper severe mosaic virus, Pepper yellow mosaic virus, Potato virus $Y$, Plum pox virus, and Pepper mottle virus, respectively. Phylogenetic analysis of the coat protein amino acid sequence revealed that this virus is a unique member of the family Potyviridae and is phylogenetically most closely related to a group of Solanaceae-infecting potyviruses rather than to other legumeinfecting potyviruses. The proposed name for the new causal agent is Chickpea yellow mosaic virus.
\end{abstract}

Chickpeas (Cicer arietinum L.) have been cultivated in different regions of Bolivia for several hundred years. They are an important cash crop for small area farmers in the highlands $(2,400$ to $3,000 \mathrm{~m}$ above sea level) of the Department of Chuquisaca in southern Bolivia. In March to May 1999 to 2001, unusual viruslike symptoms were observed in local chickpea land races in farmers' fields around Escana, Santa Rosalia, Sucre, and Yotala. Symptoms consisting of yellowing and stunting also were observed in lentils (Lens culinaris Medik.) growing in Sucre and Yotala. From inoculation studies performed in Sucre, a virus was presumed to be the

Corresponding author: R. C. Larsen

E-mail: rlarsen@pars.ars.usda.gov

Mention of a trademark or proprietary product does not constitute a guarantee or warranty of the product by the USDA and does not imply its approval to the exclusion of other products that also may be suitable. This article reports the results of research only.

Accepted for publication 5 July 2003.

Publication no. D-2003-0915-04R

This article is in the public domain and not copyrightable. It may be freely reprinted with customary crediting of the source. The American Phytopathological Society, 2003. causal agent of symptoms observed in lentil, and it appeared to be identical to the pathogen infecting chickpea. No virus symptoms were observed in pea (Pisum sativum L.) or faba bean (Vicia faba L.) growing adjacent to virus-infected chickpea or lentil. Symptoms on virus-infected chickpeas consisted of mosaic, stunting, yellowing, wilting, shortening of the internodes, and phloem discoloration. In some fields, approximately $10 \%$ of the plants exhibited the characteristic virus symptoms. Pod formation and seed yields from infected plants were greatly reduced, and seeds were often small, deformed, and discolored. In addition to local land races, virus symptoms were observed in chickpea cultivars and lines originating from the United States and the International Center for Agricultural Research in the Dry Areas (ICARDA), Syria, that were planted in observation trials in Sucre and Yotala. The U.S. cultivars consisted of Dwelley, Evans, Myles, and Sanford, and ICARDA lines included ILC 72 and ILC 3279. Lentil, pea, and chickpea infected by mechanical inoculation from symptomatic chickpea at the laboratory in Sucre further suggested that a viral agent was the cause of the disease observed in the field. Symptoms observed were unlike symptoms described for any of at least 22 different viruses reported in chickpea $(4,12,13,15,17,18,21)$. The objective of this study was to characterize the causal agent on the basis of host range, symptomatology, serological relationships, and nucleotide sequence. The name Chickpea yellow mosaic virus (CpYMV) is proposed.

\section{MATERIALS AND METHODS}

Virus source, host range, and seed transmission. Symptomatic chickpea plants were collected from the field and inoculated to Chenopodium amaranticolor Costa \& Reyne and C. quinoa Willd. Inoculation buffer was $50 \mathrm{mM}$ potassium phosphate, pH 7.4, containing $20 \mathrm{mM}$ sodium sulfite. Diatomaceous earth was included as an abrasive. Local lesions appeared in 5 to 7 days after inoculation, and three serial transfers from $C$. quinoa were made subsequently. The virus was then inoculated to and maintained in pea for additional studies. Thirty-two plant species were selected for the host range study.

Seed transmission assays were conducted using seed collected from infected pea cultivar 8221 and chickpea cultivar Dwelley mechanically inoculated with the virus. Plants were grown to maturity, and the seed was then collected from mature pods. Plants from the collected seed were allowed to grow for 10 to 14 days and then tested individually by enzyme-linked immunosorbent assay (ELISA).

Serology, virus purification, viral coat protein, and nucleic acid analysis. Preliminary examination of leaf-dip preparations with an electron microscope revealed long slightly flexuous particles ca. $760 \mathrm{nM}$ in length determined by internal size standards. As a result of these observations, pea and chickpea plants infected with the virus were evaluated by ELISA using the universal potyvirus group-specific monoclonal antibody (Agdia, Inc., Elkhart, IN), and antisera were elicited with the following members of the family Potyviridae: Bean common mosaic virus (BCMV), Bean common mosaic necrosis virus (BCMNV), Bean yellow mosaic virus (BYMV), Clover yellow vein virus (CYVV), Cowpea aphid-borne mosaic virus (CABMV), and Pea seedborne mosaic virus (PSbMV). In addition, tissue samples were tested for carlaviruses $\mathrm{Pea}$ streak virus (PeSV) and Red clover vein mosaic virus (RCVMV), and potexviruses Clover yellow mosaic virus (CYMV) and White clover mosaic virus (WCMV). 
The virus was purified from approximately $50 \mathrm{~g}$ of infected pea tissue collected 19 to 21 days postinoculation using a modified procedure of Veerisetty and Brakke (27). The final sucrose gradient described in their procedure was eliminated and replaced with a cesium gradient. The partially purified virus was adjusted to $40 \mathrm{mg} / \mu \mathrm{l}$ (wt/vol) cesium chloride and centrifuged for 15 to 18 $\mathrm{h}$ at $125,000 \times g$ at $12^{\circ} \mathrm{C}$. The light scattering band was collected, diluted in resuspension buffer $\left(16.5 \mathrm{mM} \mathrm{Na}_{2} \mathrm{HPO}_{4}\right.$ and $1.8 \mathrm{mM}$ sodium citrate, $\mathrm{pH} 8.0$ ), and centrifuged for $1 \mathrm{~h}$ at $250,000 \times g$.

Total protein preparations for Western blot analysis were made from inoculated chickpea, pea, and lentil exhibiting symptoms of the virus. Tissue was macerated in $150 \mathrm{mM}$ Tris- $\mathrm{HCl}, \mathrm{pH} 6.8$, containing $2 \%$ sodium dodecyl sulfate, 5\% 2-mercaptoethanol, and $10 \%$ glycerol. Samples were boiled for $5 \mathrm{~min}$, chilled on ice, and then centrifuged for $5 \mathrm{~min}$ at $12,000 \times \mathrm{g}$. Sample preparations were resolved on $12 \%$ discontinuous sodium dodecyl sulfate (SDS) polyacrylamide gels (20) and then electroblotted onto $0.45-\mu \mathrm{m}$ nitrocellulose membranes (26). The blots were probed overnight at room temperature using the potyvirus group-specific monoclonal antibody at a dilution rate of 1:1,000. The blots were then washed and probed with goat anti-mouse alkaline phosphatase (Bio-Rad, Hercules, CA) at a 1:2,000 dilution, washed after $1 \mathrm{~h}$, and then visualized with nitro blue tetrazolium and 5-bromo-4chloro-3-indoyl phosphate substrate (Sigma Chemical Co., St. Louis, MO) (3). Protein molecular weight was determined by the use of low-molecular-weight prestained protein standards (Bio-Rad, Hercules, CA). Protein samples from purified virions were prepared in a similar manner. Protein bands in polyacrylamide gel electrophoresis (PAGE) gels were visualized after staining with a $2 \%$ aqueous solution of silver nitrate. Molecular weight was determined by use of molecular weight standards (Sigma).

RNA was extracted from purified virions $(1 \mathrm{mg} / \mathrm{ml})$ in $260 \mu \mathrm{l}$ of resuspension buffer by the addition of $3 \mu \mathrm{l}$ of $0.1 \mathrm{M}$ dithiothreitol, $7 \mu$ l of proteinase $\mathrm{K}$ (10 $\mathrm{mg} / \mathrm{ml}$ ), and $30 \mu \mathrm{l}$ of $10 \%$ SDS. Extracts were incubated $30 \mathrm{~min}$ at $37^{\circ} \mathrm{C}$. The proteinase $\mathrm{K}$ was denatured using an equal volume of Tris-saturated phenol $(\mathrm{pH} \mathrm{8.0)}$ and chloroform. After separation by centrifugation, the viral nucleic acid was concentrated by ethanol precipitation.

The molecular size of the viral RNA was determined by agarose gel electrophoresis after denaturation with glyoxal and dimethylsulfoxide (DMSO) (23). RNA was electrophoresed in $1.2 \%$ agarose using 10 $\mathrm{mM}$ sodium phosphate buffer, $\mathrm{pH}$ 6.8. A 0.24- to 9.5-kb RNA ladder (Gibco, Gaithersburg, MD) was used for molecular size standards. Following electrophoresis, glyoxal was removed from gels by agitation for $15 \mathrm{~min}$ in TAE buffer $(40 \mathrm{mM}$
Tris, $\mathrm{pH}$ 8.0, $20 \mathrm{mM}$ sodium acetate, $1 \mathrm{mM}$ EDTA). Gels were stained with ethidium bromide and observed on a transilluminator at $300 \mathrm{nM}$. Images were recorded and stored using an AlphaImager 2000 (Alpha Innotech, San Leandro, CA).

Electron microscopy. Virus samples or purified virions. Samples were applied to carbon-coated Formvar 300-mesh grids and stained with an aqueous solution of $2 \%$ uranyl acetate. Preparations were observed using a JEOL 1010 transmission electron microscope. Particle lengths were determined using an internal size standard.

Synthesis of cDNA. First-strand cDNA synthesis was carried out using the method described previously by Wyatt et al. (28). Second-strand synthesis was performed essentially using the procedure of Gubler and Hoffman (6). Double-stranded cDNA was blunt-end ligated into EcoRV-digested pBluescript II SK+ vector. Plasmids were transformed into E. coli DH10 $\beta$ competent cells. Cells were grown on a selective medium containing X-Gal and IPTG as described by Sambrook et al. (25). White colonies containing plasmids with inserts of at least $2 \mathrm{~kb}$ in size, as determined by restriction enzyme mapping, were amplified in Luria Broth media containing 50 $\mu \mathrm{g} / \mu \mathrm{l}$ ampicillin. The plasmids were isolated by alkaline lysis (25) and the doublestranded DNA prepared for sequencing. Sequence reactions of the forward and were prepared from leaf dip preparations

complementary strands were analyzed using an automated dye termination system (ABI, Inc.). Sequence data were further analyzed using Align Plus (Scientific and Educational Software, Cary, NC). Coat protein sequences of all members of the Potyviridae for which these data are available were aligned using PILEUP (Accelrys, San Diego, CA). Based on a preliminary phylogenetic analysis using the neighbor-joining method, to reduce computing requirements the 25 taxa closely related to CpYMV were chosen for more detailed phylogenetic analysis, paying particular attention to legume-infecting members of the group. In order to further simplify the analysis, only one member of a subgroup (e.g., the BCMV subgroup of the genus Potyvirus) was used. A Bayesian inference of phylogenetic relationships was done using the software MrBayes (Huelsenbeck and Ronquist: http://morphbank. ebc.uu.se/mrbayes/). The log likelihood sum reached a plateau after about 3,000 generations, and data from 7,000 additional generations were collected. A consensus tree was calculated, as were clade probabilities. To verify the robustness of the inference, the multiple sequence alignment was also analyzed using maximum parsimony.

\section{RESULTS}

Virus purification. The virus preparation after centrifugation in cesium chloride resulted in two light-scattering zones at 2.5

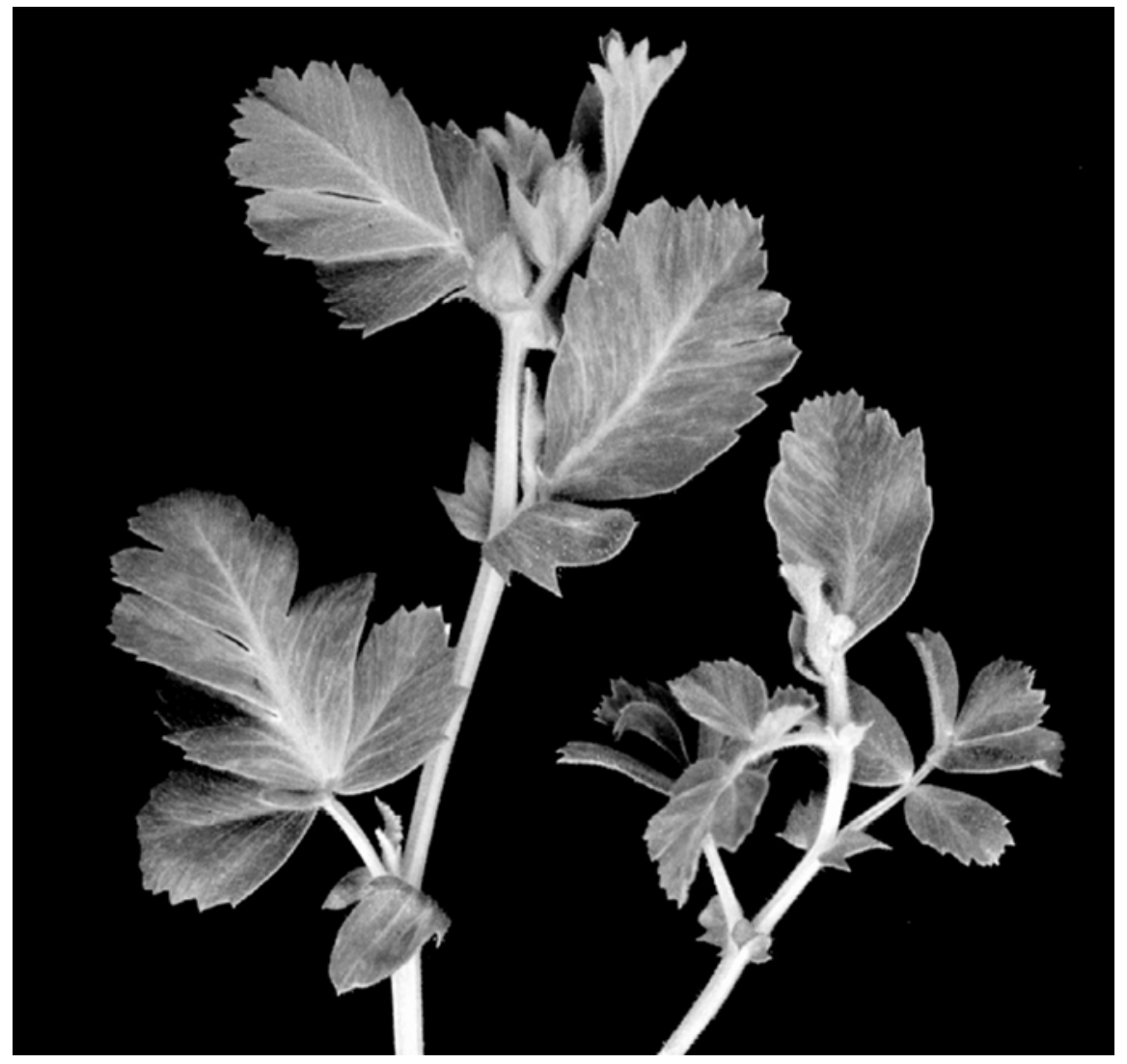

Fig. 1. Mosaic symptoms on leaves of chickpea cv. Dwelley infected with Chickpea yellow mosaic virus. 
and $3.6 \mathrm{~mm}$ below the meniscus. The upper band was a nonfluorescing zone and was determined to be a nonviral contaminant as determined by observation using electron microscopy. The fluorescent zone at $3.6 \mathrm{~mm}$ consisted of flexuous rodshaped particles and averaged $2.48 \mathrm{OD}_{260}$ units for $50 \mathrm{~g}$ of tissue. The average $A_{260} / A_{280}$ ratio was 1.34 .

Host range. The virus induced systemic infection in several legume species, including Cicer arietinum, Lens culinaris, Medicago sativa L., and Pisum sativum. Local lesions occurred without systemic spread in Chenopodium quinoa, C. amaranticolor, and Phaseolus vulgaris L. Symptoms in pea included pronounced mosaic, mottle, and greening of veins. Symptoms on chickpea were consistent with those observed naturally infected in the field (Fig. 1). No stunting of plants that occurred in
A

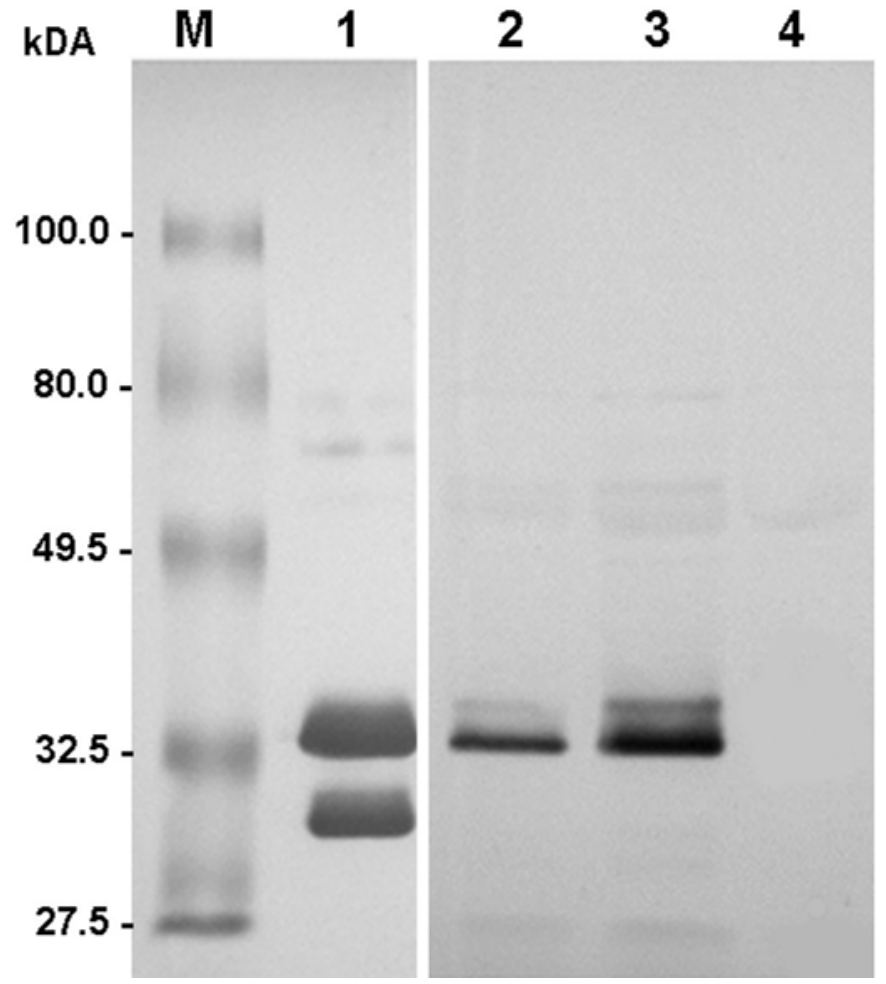

B

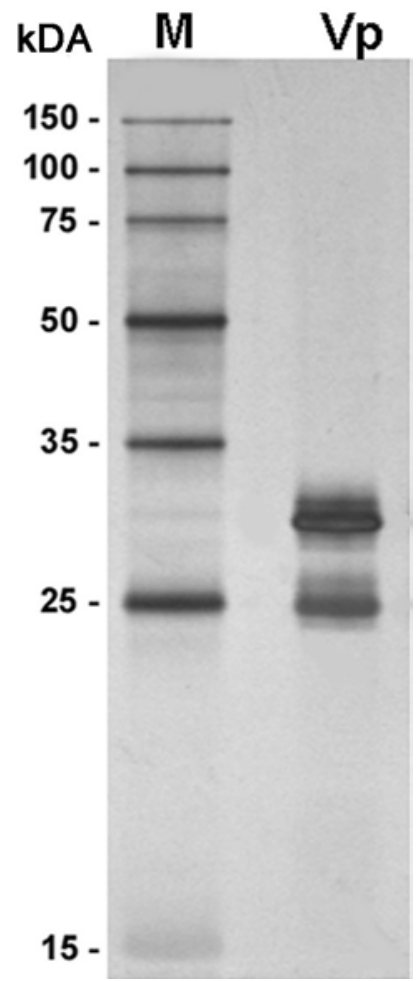

Fig. 2. A, Western blots of Chickpea yellow mosaic virus probed with the potyvirus group-specific monoclonal antibody. Lane M: prestained protein molecular weight marker, lane 1: nucleoprotein prepared from purified virions, lane 2: total protein preparation from chickpea (Cicer arietinum) cv. Dwelley, lane 3: total protein preparation from pea (Pisum sativum) cv. Dark Skin Perfection, lane 4: healthy chickpea. B, Silver-stained virus protein preparations of Chickpea yellow mosaic virus purified from pea and resolved by sodium dodecyl sulfate-polyacrylamide gel electrophoresis (SDS-PAGE). Lane M: protein molecular weight marker, lane $\mathrm{Vp}$ : virus protein.

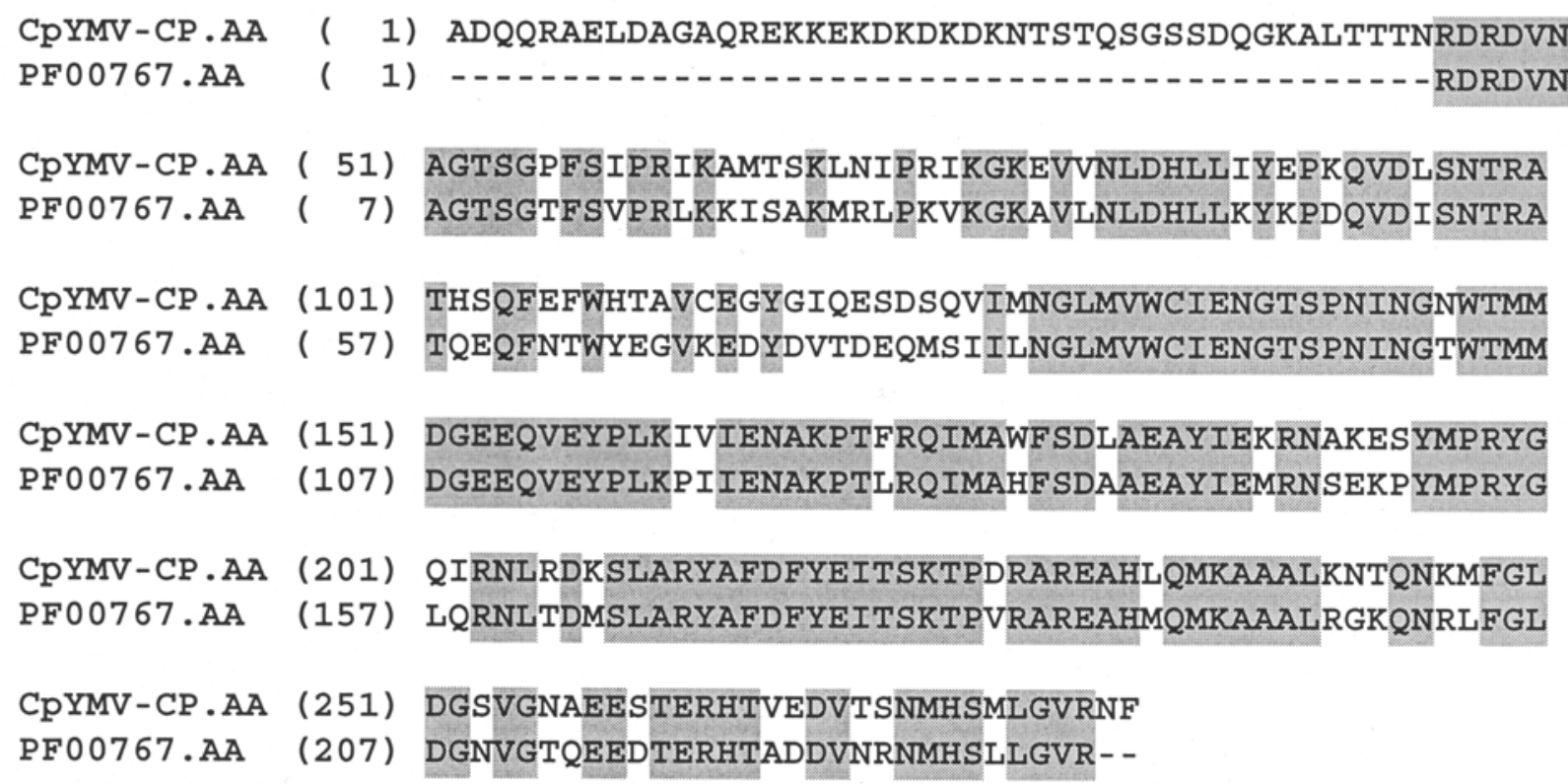

Fig. 3. Alignment of Chickpea yellow mosaic virus deduced coat protein amino acid sequence (CpYMV-CP.AA) with potyvirus coat protein contained in the GenBank Conserved Domain Database (pfam 00767). Conserved sequence is highlighted in shaded blocks. 
chickpea and lentil was observed in pea. Local lesions were noted on inoculated leaves of alfalfa, but systemic symptoms were absent. No symptoms were produced on, and no virus was detected in: Beta vulgaris L., Cassia occidentalis L., Cисиmis sativus L., Cucurbita pepo L., Datura tatula L., Glycine max (L.) Merr., Gomphrena globosa L., Lycopersicon esculentum Mill., Nicotiana tabacum 'Occidentalis', N. tabacum 'Rustica', N. tabacum 'Samsun', N. tabacum 'Xanthi', Trifolium pratense L., T. repens L., Trigonella foenum-graecum L., Vicia faba, and Vigna unguiculata (L.) Walp.

Serology, viral coat protein, and nucleic acid analysis. Chickpea and pea tissue exhibiting the described symptoms reacted positively in ELISA to the potyvirus monoclonal antibody; however, reactions using antisera elicited with the potyviruses BCMV, BCMNV, BYMV, CYVV, CABMV, and PSbMV were negative. Reactions were also negative when sympto- matic tissue was tested for PeSV, RCVMV, CYMV, and WCMV.

When total protein sample preparations on Western blots were probed with the potyvirus monoclonal antibody, a single band ca. $32 \mathrm{kDa}$ was observed (Fig. 2). In contrast, two distinct bands ca. 32 and 28 $\mathrm{kDa}$ were produced from purified virus preparations (Fig. 2). Similar results were observed when purified virus protein preparations were resolved by SDS-PAGE and silver stained (Fig. 2). Purified virion

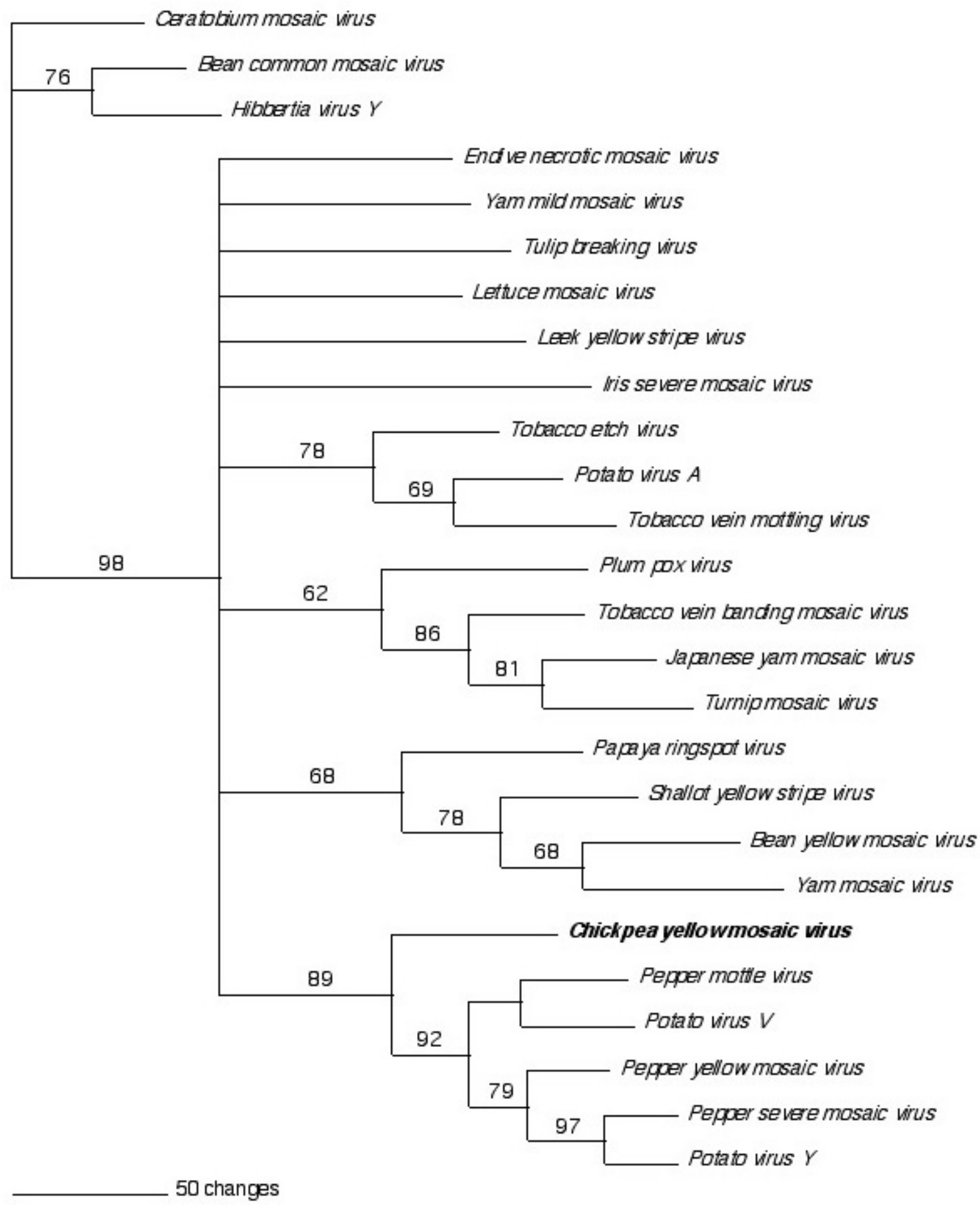

Fig. 4. Bayesian phylogenetic inference based on the coat protein amino acid sequence of representative members of the genus Potyvirus. Branch lengths are proportional to distance, and the numbers presented on certain branches of the tree reflect clade probabilities, when $>50 \%$, indicating the level of support for branches of the tree. 
RNA denatured in glyoxal and DMSO resolved as a single band in agarose gels (data not shown). The molecular size was determined to be approximately $9.45 \mathrm{~kb}$.

Seed transmission. Four hundred seed collected from infected pea 'Dark Skin Perfection' and 50 seed from infected chickpea 'Dwelley' were germinated and observed to be symptomless during a 21-day examination period. ELISAs performed 10 days after emergence were negative for the virus when evaluated using the universal potyvirus monoclonal antibody.

cDNA synthesis and sequence analysis. In cDNA synthesis and cloning experiments, 3 '-end cDNA clones of the viral RNA consisted of a poly-A tail 12 to 26 nucleotides in length. The deduced amino acid sequence obtained through the coat protein (GenBank accession no. AF527897) region was consistent with the genome arrangement of the Potyviridae. The putative coat protein gene beginning 235 nucleotides upstream from the poly-A tail consisted of 846 nucleotides encoding 282 amino acids.

Analysis of the deduced amino acid sequence at the $5^{\prime}$-region of the coat protein gene revealed a motif similar to several other potyviruses and suggests the potential cleavage site that represents the $\mathrm{N}$ terminus of the gene (Fig. 3). The Nterminus begins with an alanine residue that is preceded by the probable $\mathrm{NIb} / \mathrm{CP}$ cleavage site VQHQ as identified by analogy to consensus sequences and genome arrangement in other potyviruses. The sequence DAG that is typically associated with aphid transmissible potyviruses (2) is located eight amino acids downstream from the coat protein N-terminus. An 11-aa sequence RDRDVNAGTSG that is highly conserved with other coat proteins within the Potyviridae (GenBank PF00767) was identified using BLAST (1), and begins 45 amino acids downstream from the putative $\mathrm{N}$-terminus of the coat protein (Fig. 3). The 3 '-end sequence LGVRNF occurs immediately prior to a TAA ochre codon. The estimated molecular weight of the putative coat protein is 31,953 .

The coat protein amino acid sequence was analyzed for phylogenetic relationships with other members of the Potyviridae. Topologies of trees predicted using maximum parsimony (data not shown) or Bayesian inference were similar (Fig. 4). This analysis indicated that CpYMV was on a distinct branch of the phylogenetic tree, whose clade probabilities were well supported. Other viruses that shared the same branch of the tree were Potato virus $Y$, Pepper mottle virus, and other related viruses of the Solanaceae. CpYMV did not show any obvious phylogenetic relationship to legume-infecting viruses such as BCMV or BYMV.

\section{DISCUSSION}

Results obtained in this study indicate that CpYMV is a new and unique virus that affects a limited number of crop plants in the family Leguminosae. The virus was observed to be most severe in naturally infected chickpea fields in the Department of Chuquisaca in Bolivia. It is presently not known if the virus occurs within other countries of South America. Symptom expression on experimentally infected pea was dramatic on leaves, but the virus produced little stunting and had no observed deleterious effects on pod and seed production. Although the sample size examined was relatively low, the virus was not seedtransmitted in pea or chickpea. These results are unusual for a potyvirus that commonly infects legumes. For example, BCMV, BCMNV, BYMV, PSbMV, CABMV, and Southern bean mosaic virus are each transmissible by seed from at least one common legume host $(5,7,8,11,14,16$, 19,22). It is possible that CpYMV may be transmitted by seed of alfalfa or lentil, identified as additional systemic hosts of this virus, but these species were not evaluated further. Natural reservoir hosts for the virus are currently unknown. However, because alfalfa is grown as a crop in the Sucre region of Bolivia, it may be considered a perennial host if natural infection in the field can be verified. Although vector transmission studies were not conducted, CpYMV is presumed to be aphidborne, and a consistent presence of the pea aphid (Acyrthosiphon pisum) was observed within infected fields of chickpea in the Chuquisaca region. While not conclusive, these observations provide circumstantial evidence that the pea aphid may be involved in transmission of the virus. Peas growing in areas near chickpea fields where infections were observed did not exhibit symptoms similar to those observed in pea inoculated experimentally. It is possible that the indigenous pea aphid biotype present in Sucre was not able to transmit CpYMV to pea plants growing in the area. There is also the potential that pea lines being grown in the field in Sucre have resistance to the virus through selection by farmers. Local farmers have been growing the same pea lines (land races) for years and usually save their own seed for subsequent planting. Therefore, it is not possible to identify the lines or where they originated.

Comparison of the deduced amino acid sequence of the CpYMV putative coat protein, while clearly a member of the genus Potyvirus, has shown that CpYMV is distantly related to all other potyviruses for which coat protein amino acid sequence data are available, with the largest percent identity at $67 \%$ with PepSMV. The coat protein sequence is more distantly related to potyviruses primarily affecting legume crops including BYMV (62\% identity), BCMV (58\%), and PSbMV (57\%). The low percentage of identities is consistent with the lack of cross-reactivity with antibodies to these viruses. The predicted coat protein amino acid molecular weight of 31,953 is also consistent with the ca. 32$\mathrm{kDa}$ band produced on Western blots of total nucleic extractions from tissue infected with CpYMV. The additional 28$\mathrm{kDa}$ protein band visualized from Western blots of purified virus preparations is likely a degradation product artifact resulting from proteolysis of the virus coat protein $(9,10,24)$. Based on the presence of the highly conserved potyvirus sequence RDRDVNAGTSG within the coat protein, the positive reaction to the potyvirus monoclonal antibody, particle size and morphology, and coat protein molecular weight, sufficient evidence exists to place CpYMV as a distinct species of the genus Potyvirus, family Potyviridae.

\section{LITERATURE CITED}

1. Altschul, S. F., Madden, T. L., Schäffer, A. A., Zhang, J., Zhang, Z., Miller, W., and Lipman, D. J. 1997. Gapped BLAST and PSI-BLAST: A new generation of protein database search programs. Nucleic Acids Res. 25:3389-3402.

2. Atreya, P. L., Atreya, C. D., and Pirone, T. P. 1991. Amino acid substitutions in the coat protein result in loss of insect transmissibililty of a plant virus. Proc. Nat. Acad. Sci. U.S.A. 88:7887-7891.

3. Blake, M. S., Johnston, K. H., Russel-Jones, G. J., and Gotschlich, E. C. 1984. A rapid, sensitive method for detection of alkaline phosphatase-conjugated anti-antibody on western blots. Anal. Biochem. 136:175-179.

4. Bosque-Perez, N. A., and Buddenhagen, I. W. 1990. Studies on epidemiology of virus disease of chickpea in California. Plant Dis. 74:372-378.

5. Bowers, G. R., and Goodman, R. M. 1979. Soybean mosaic virus: Infection of soybean seed parts and seed transmission. Phytopathology 69:569-572.

6. Gubler, U., and Hoffman, B. J. 1983. A simple and very efficient method for generating cDNA libraries. Gene 25:263-269.

7. Hampton, R. O., and Mink, G. I. 1975. Pea seedborne mosaic virus. CMI/AAB Descr. Plant Viruses No. 146.

8. Hampton, R. O., and Muehlbauer, F. J. 1977 Seed transmission of the pea seedborne mosaic virus in lentils. Plant Dis. Rep. 61:235238.

9. Hiebert, E., and McDonald, J. G. 1976. Capsid protein heterogeneity in turnip mosaic virus. Virology 70:144-150.

10. Hiebert, E., Tremaine, J. H., and Ronald, W. P. 1984. The effect of limited proteolysis on the amino acid composition of five potyviruses and on the serological reaction and peptide map of the tobacco etch virus capsid protein. Phytopathology 74:411-416.

11. Kaiser, W. J. 1972. Seed transmission of bean yellow mosaic virus in broad beans in Iran Phytopathology 62:768.

12. Kaiser, W. J., Danesh, D., Okhovat, M., and Mossahebi, H. 1968. Diseases of pulse crops (edible legumes) in Iran. FAO Plant Prot. Bull. 23, 33-39.

13. Kaiser, W. J., Ghanekar, A. M., Nene, Y. L., Rao, B. S., and Anjaiah, V. 1990. Viral diseases of chickpea. Pages 139-142 in: Chickpea in the nineties. Proc. Int. Workshop Chickpea Improv. 2nd. ICRISAT, Patancheru, India.

14. Kaiser, W. J., Klein, R. E., Larsen, R. C., and Wyatt, S. D. 1993. Chickpea wilt incited by pea streak carlavirus. Plant Dis. 77:922-926.

15. Kaiser, W. J., Mossahebi, G. M., and Okhovat, 
M. 1971. Alternate hosts of viruses affecting food legumes in Iran. Iranian J. Plant Pathol. 7:25-29, 85-93.

16. Kaiser, W. J., and Wyatt, S. D. 1985. Virus diseases of chickpea in Idaho and Washington. (Abstr.) Phytopathology 75:1310-1311.

17. Kaiser, W. J., Wyatt, S. D., Hannan, R. M., and Cody, Y. 1988. Chickpea filiform, a new viral disease of Cicer arietinum. Plant Dis. 72:70-74.

18. Katul, L., Vetten, H. J., Maiss, E., Makkouk, K. M., Lesemann, D.-E., and Casper, R. 1993. Characterization and serology of virus-like particles associated with faba bean necrotic yellows. Ann. Appl. Biol. 123:629-647.

19. Kendrick, J. B., and Gardner, M. W. 1924. Soybean mosaic virus: Seed transmission and effect on yield. J. Agric. Res 27:91-95.
20. Laemmli, U. K. 1970. Cleavage of structural proteins during the assembly of the head of bacteriophage T4. Nature 227:680-685.

21. Larsen, R. C., Kaiser, W. J., and Wyatt, S. D. 1996. First report of a virus disease of chickpea caused by a strain of red clover vein mosaic carlavirus. Plant Dis. 80:709.

22. Mali, V. R., and Kulthe, K. S. 1980. A seedborne potyvirus causing mosaic of cowpea in India. Plant Dis. 64:925-928.

23. McMaster, G. K., and Carmichael, G. G. 1977. Analysis of single- and double-stranded nucleic acids on polyacrylamide and agarose gels by using glyoxal and acridine orange. Proc. Nat. Acad. Sci. 74:4835-4838.

24. Moghal, S. M., and Francki, R. I. B. 1976. Towards a system for the identification and classification of potyviruses. I. Serology and amino acid composition of six distinct viruses. Virology 73:350-362.

25. Sambrook, J., Fritsch, E. F., and Maniatis, T 1989. Molecular Cloning: A Laboratory Manual. 2nd ed. Cold Spring Harbor Laboratory, Cold Spring Harbor, NY.

26. Towbin, H., Staehelin, T., and Gordon, J. 1979. Electrophoretic transfer of proteins from polyacrylamide gels to nitrocellulose sheets: Procedure and some applications. Proc. Nat. Acad. Sci. U.S.A. 76:4350-5354.

27. Veerisetty, V., and Brakke, M. K. 1978. Purification of some legume carlaviruses. Phytopathology 68:59-64.

28. Wyatt, S. D., Druffel, K., and Berger, P. H 1993. In vitro destabilization of plant viruses and cDNA synthesis. J. Virol. Methods 44:211-220. 